\title{
PERBANYAKAN IN VITRO PISANG KEPOK var. UNTI SAYANG TAHAN PENYAKIT DARAH MELALUI PROLIFERASI TUNAS
}

\author{
In Vitro Propagation of Kepok Banana var. Unti Sayang Resistant to Blood \\ Disease through Shoot Proliferation \\ Maria Imelda, Aida Wulansari*, Laela Sari \\ Pusat Penelitian Bioteknologi LIPI. Jalan Raya Bogor Km 46, Cibinong 16911, Jawa Barat \\ *E-mail: aida_wulansari@yahoo.com
}

\begin{abstract}
Kepok is a popular banana variety but sensitive to blood disease caused by Ralstonia solanacearum (Smith). The discovery of a natural mutant of Kepok banana var. Unti Sayang from Sulawesi which male bud falls naturally, is a shortcut to bypass the chains of the spread of blood disease, since the disease is transmitted by insects through the wounds of the male buds. The superior mutant needs to be mass propagated and disseminated to endemic areas to inhibit the spread of blood disease. To achieve that goal, an efficient and effective techniques of in vitro shoot proliferation needs to be developed. Shoot proliferation was performed by addition of BAP, thidiazuron and adenine sulphate. The results showed that the best medium for shoot multiplication was $B_{2} T_{5} A(M S+2 \mathrm{mg} / \mathrm{L} B A P+0,5 \mathrm{mg} / \mathrm{L} T D Z+20$ $\mathrm{mg} / \mathrm{L}$ adenine sulphate), and for shoot growth was $B_{4} A(M S+4 \mathrm{mg} / \mathrm{L} B A P+20 \mathrm{mg} / \mathrm{L}$ adenine sulphate). Rooting was induced on MS medium without hormones. Acclimatization of plantlets on mixed soil, compost and husks with a ratio of 1:1:1 resulted in 92,35\% survival rate.
\end{abstract}

Keywords: blood disease, in vitro shoot, male budless, natural mutant, var. Unti Sayang

\begin{abstract}
ABSTRAK
Pisang kepok merupakan varietas yang digemari tetapi sangat peka terhadap penyakit darah yang ditimbulkan oleh bakteri Ralstonia solanacearum (Smith). Ditemukannya mutan alami pisang kepok yang jantungnya gugur secara alami yaitu varietas Unti Sayang dari Sulawesi, merupakan jalan pintas untuk memotong rantai penyebaran penyakit darah, mengingat penyakit ini ditularkan oleh serangga melalui luka bekas bunga jantan pada jantung. Mutan unggul tersebut perlu diperbanyak secara massal dan disebarluaskan ke daerah endemik untuk menghambat penyebaran penyakit darah. Untuk mencapai tujuan tersebut, perlu dikembangkan teknik perbanyakan in vitro pisang kepok Unti Sayang yang efektif dan efisien melalui proliferasi tunas. Proliferasi tunas dilakukan dengan penambahan BAP, thidiazuron dan adenin sulfat. Hasil penelitian ini menunjukkan bahwa media terbaik untuk multiplikasi tunas adalah $\mathrm{B}_{2} \mathrm{~T}_{5} \mathrm{~A}$ (MS+2 $\mathrm{mg} / \mathrm{L} \mathrm{BAP}+0,5 \mathrm{mg} / \mathrm{L} \mathrm{TDZ}+20 \mathrm{mg} / \mathrm{L}$ adenin sulfat), media terbaik untuk pertumbuhan tunas adalah $\mathrm{B}_{4} \mathrm{~A}(\mathrm{MS}+4 \mathrm{mg} / \mathrm{L} \mathrm{BAP}+20 \mathrm{mg} / \mathrm{L}$ adenin sulfat). Akar dapat diinduksi pada media MS tanpa hormon. Aklimatisasi planlet pada media campuran tanah, kompos dan sekam dengan perbandingan 1:1:1 menghasilkan 92,35\% planlet hidup.
\end{abstract}

Kata Kunci: penyakit darah, tunas in vitro, tanpa jantung, mutan alami, var. Unti Sayang 


\section{PENDAHULUAN}

Pisang merupakan salah satu komoditas unggulan Indonesia yang berpotensi menunjang ketahanan pangan nasional. Pisang termasuk buah yang banyak digemari, nutrisinya tinggi dan hampir semua bagian tanaman dapat dimanfaatkan. Pisang juga memiliki produktivitas dan daya adaptasi yang tinggi (Suhartanto et al. 2012). Selain itu harga pisang terjangkau dan dapat dikonsumsi baik sebagai buah segar maupun dalam bentuk olahan.

Pisang kepok merupakan salah satu jenis pisang olahan. Pisang kepok memiliki nilai ekonomis yang tinggi karena rasanya yang enak dan manis dengan kadar gula mencapai 300 Brix (Poerba et al. 2012). Salah satu jenis pisang kepok yang dibudidayakan di daerah Sulawesi Selatan yaitu pisang kepok (Musa acuminata $x$ M. balbisiana) var. Unti Sayang atau dikenal juga dengan nama pisang Amorang. Berdasarkan deskripsi pada SK Mentan Nomor 2048/Kpts/SR.120/5/2010 tentang pelepasan pisang kepok Unti Sayang sebagai varietas unggul disebutkan bahwa pisang ini memiliki keunggulan produktivitas tinggi, tidak memiliki bunga jantan, kulit buah berwarna kuning dan halus, daging buah berwarna kuning dengan rasa manis, buah tidak mudah lepas dari sisirnya serta beradaptasi dengan baik di dataran rendah. Produktivitas pisang kepok var. Unti Sayang mencapai $40 \mathrm{~kg}$ per tanaman (Suhartanto et al. 2012).

Pisang kepok var. Unti Sayang sulit diserang penyakit layu bakteri dan penyakit darah karena memiliki pertahanan alami yaitu tidak mempunyai jantung (bunga jantan) sehingga terhindar dari serangan serangga vektor kedua penyakit tersebut (Poerba et al. 2012). Menurut Hermanto dan Emilda (2013) pada percobaan lapang di daerah endemik penyakit darah, pisang kepok yang tidak memiliki bunga jantan atau jantung terbukti lebih tahan terhadap penyakit darah dibandingkan pisang kepok yang berjantung.

Penyebab penyakit darah adalah bakteri Ralstonia solanacearum (Smith) (dahulu dinamakan Pseudomonas solanacearum) (Maramis 2014). Cara penularannya adalah oleh bakteri yang masuk melalui bekas luka dari bunga jantan yang gugur. Pada tahap selanjutnya, bakteri dapat ditularkan melalui tanah yang terbawa air dan menginfeksi melalui luka pada akar (Supriati 2010). Selama ini cara mengurangi penyebaran penyakit darah yang paling efektif adalah dengan membuang jantungnya setelah semua bunga betina menjadi buah. Namun, pada areal yang luas cara tersebut tidak efisien karena sulit untuk menghilangkan jantung dari setiap tanaman, selain memakan banyak waktu dan tenaga kerja. Ditemukannya pisang kepok var. Unti Sayang yang jantungnya gugur setelah semua bunga betina menjadi buah (male budless mutant) sangat membantu dalam memotong rantai penyebaran penyakit darah.

Penularan penyakit juga dapat terjadi melalui penanaman bibit yang sudah terinfeksi, tapi hal ini dapat diatasi dengan penggunaan bibit hasil kultur jaringan yang bersih dari penyakit (Eden-Green 1994). Bibit pisang hasil kultur jaringan telah banyak digunakan untuk menghindari penularan penyakit. Teknik kultur jaringan lebih efektif dan efisien dalam menghasilkan bibit secara massal dalam waktu yang relatif lebih singkat dibandingkan metode konvensional. Bibit tersebut tetap memiliki sifat unggul dari induknya dengan tingkat keseragaman yang cukup tinggi. Selain itu, penyediaan bibit pisang hasil kultur jaringan secara komersial dapat dijadwalkan sesuai kebutuhan (Supriati 2010).

Penggunaan media dasar dan zat pengatur tumbuh (ZPT) yang tepat merupakan faktor penting yang perlu diperhatikan dalam perbanyakan bibit menggunakan teknik kultur jaringan sehingga dapat diperoleh hasil yang optimum. Tujuan penelitian ini adalah untuk mengembangkan teknologi perbanyakan tanaman pisang kepok var. Unti Sayang yang tahan penyakit darah melalui proliferasi tunas in vitro dalam menunjang penyediaan bibit secara massal untuk disebarluaskan ke daerah endemik sebagai jalan pintas dalam memotong rantai penyebaran penyakit darah.

\section{BAHAN DAN METODE}

\section{Bahan}

Bahan tanaman yang digunakan sebagai sumber eksplan adalah anakan pisang kepok Unti Sayang yang sehat berukuran sekitar $40 \mathrm{~cm}$. Bahan-bahan 
untuk pembuatan media dasar MS (Murashige dan Skoog 1962), BAP, TDZ, adenin sulfat, bahan pemadat (agar), sukrosa, aquades, sabun pencuci, larutan desinfektan 30\% (bahan aktif $\mathrm{NaClO} 5,25 \%$ ) dan aquades steril. Alat-alat yang digunakan adalah timbangan analitik, $\mathrm{pH}$ meter, autoklaf, laminar air flow cabinet, botol kultur, cawan petri, scalpel, pinset, pembakar Bunsen, beaker glass, pipet ukur, magnetic stirrer, kertas saring dan plastic wrap.

\section{Metode}

\section{Inisiasi kultur}

Anakan pisang yang sehat dan berukuran $40 \mathrm{~cm}$ dibuang akar dan pucuknya, demikian pula seludang bagian luar dan bonggol bawahnya sampai berukuran $\pm 10 \mathrm{~cm}$. Selanjutnya bahan tersebut dicuci bersih dengan air mengalir lalu disterilkan dalam larutan desinfektan $30 \%$ (bahan aktif $\mathrm{NaClO} 5,25 \%$ ) selama 30

Tabel 1. Perlakuan zat pengatur tumbuh (ZPT)

\begin{tabular}{cccc}
\hline \multicolumn{2}{l}{ Konsentrasi ZPT $(\mathrm{mg} / \mathrm{L})$} & \multirow{2}{*}{ Kode media } \\
\cline { 1 - 2 } BAP & TDZ & Adenin & \\
\hline 1 & 0 & 0 & B1 \\
1 & 0 & 20 & B1A \\
1 & 0,5 & 0 & B1T5 \\
1 & 0,5 & 20 & B1T5A \\
2 & 0 & 0 & B2 \\
2 & 0 & 20 & B2A \\
2 & 0,5 & 0 & B2T5 \\
2 & 0,5 & 20 & B2T5A \\
3 & 0 & 0 & B3 \\
3 & 0 & 20 & B3A \\
3 & 0,5 & 0 & B3T5 \\
3 & 0,5 & 20 & B3T5A \\
4 & 0 & 0 & B4 \\
4 & 0 & 20 & B4A \\
4 & 0,5 & 0 & B4T5 \\
4 & 0,5 & 20 & B4T5A \\
5 & 0 & 0 & B5 \\
5 & 0 & 20 & B5A \\
5 & 0,5 & 0 & B5T5 \\
5 & 0,5 & 20 & B5T5A \\
0 & 0 & 0 & Kontrol \\
\hline & & &
\end{tabular}

menit dan dibilas beberapa kali dengan aquades steril. Semua pekerjaan tersebut dilakukan dalam laminar air flow cabinet. Setelah itu seludang luarnya dibuang lagi beberapa lapis, begitu juga bonggol bawah dan pucuknya hingga mencapai ukuran $\pm 1,5$ $\mathrm{cm}$ dan dibelah 4 kemudian ditanam dalam media MS yang telah disiapkan sebelumnya. Semua kultur tersebut diinkubasikan selama 4 minggu dalam ruangan bersuhu $25-26^{\circ} \mathrm{C}$ dengan pencahayaan 16 jam per hari.

\section{Proliferasi dan pengakaran tunas}

Media yang digunakan untuk proliferasi tunas in vitro adalah media padat dengan komposisi MS, penambahan sukrosa $20 \mathrm{~g}$ dan gelrite $2,5 \mathrm{~g} / \mathrm{L}$. Kemasaman media diatur sampai mencapai $\mathrm{pH}$ 5,8 dengan penambahan larutan $\mathrm{KOH}$ atau $\mathrm{HCl}$. Selanjutnya media diautoklaf pada suhu $121^{\circ} \mathrm{C}$ dan tekanan 1 atm selama 15 menit. Perlakuan yang diberikan untuk menginduksi proliferasi tunas adalah penambahan zat pengatur tumbuh BAP sebanyak 2-5 $\mathrm{mg} / \mathrm{L}$, baik dengan maupun tanpa thidiazuron (TDZ) $0,5 \mathrm{mg} / \mathrm{L}$ dan adenin sulfat $20 \mathrm{mg} / \mathrm{L}$ ke dalam media MS (Tabel 1). Semua kultur perlakuan diinkubasikan selama 12 minggu dalam ruangan bersuhu $25-26^{\circ} \mathrm{C}$ dengan pencahayaan 16 jam per hari. Parameter yang diamati yaitu jumlah tunas dan tinggi tunas setiap 4 minggu.

Pengakaran tunas dilakukan pada media MS tanpa ZPT. Tunas yang sudah besar dipisahkan dari tunas anakan yang masih kecil, kemudian ditanam pada media tanpa ZPT untuk menginduksi akar.

\section{Aklimatisasi planlet}

Planlet yang sudah cukup besar dan berakar banyak dibersihkan dari sisa-sisa agar dengan menambahkan air ke dalam botol kultur sehingga tidak banyak akar yang rusak. Selanjutnya akar planlet tersebut dicuci dengan air mengalir dan dikeringkan. Setelah itu planlet ditanam dalam pot plastik berisi media tanah, kompos dan sekam bakar (1:1:1), yang telah disiram sampai jenuh. Pot disungkup dengan kantung plastik transparan yang telah dilubangi selama \pm 2 minggu sampai muncul daun baru dan ditempatkan dalam kamar kaca. 


\section{Analisis data}

Penelitian

ini

menggunakan

Rancangan Acak Lengkap. Setiap perlakuan diulang 3 kali (botol) dan setiap botol berisi 3 eksplan. Hasil penelitian dianalisis menggunakan Analysis of Variance (ANOVA) dan dilanjutkan dengan Duncan Multiple Range Test (DMRT) pada taraf nyata $5 \%$.

\section{HASIL DAN PEMBAHASAN}

\section{Inisiasi kultur}

Eksplan berupa potongan bonggol pisang yang dikulturkan pada media MS tanpa penambahan ZPT mulai tumbuh sekitar 7-10 hari setelah tanam. Pada tahap selanjutnya eksplan yang tidak dipindahkan ke media yang mengandung ZPT menghasilkan tunas tunggal.

\section{Proliferasi dan pertumbuhan tunas}

Tunas tunggal yang disubkultur ke media MS dengan penambahan ZPT dari kelompok sitokinin (BAP dan TDZ) serta adenin sulfat menghasilkan tunas majemuk (Gambar 1). Pada konsentrasi yang tepat, kombinasi pemberian zat pengatur tumbuh BAP dan TDZ serta adenin sulfat dapat menghasilkan banyak sekali tunas. Tunas terbanyak diperoleh pada media $B_{2} T_{5} A$ (2 $\mathrm{mg} / \mathrm{L}$ BAP, $0,5 \mathrm{mg} / \mathrm{L}$ TDZ dan $20 \mathrm{mg} / \mathrm{L}$ adenin sulfat) yang menghasilkan 35,44 tunas pada umur 8 minggu dan 36,81 tunas pada umur 12 minggu. Pada media kontrol, tunas yang dihasilkan hanya 3 pada umur 12 minggu (Tabel 2).

Pengamatan terhadap jumlah tunas yang terbentuk menunjukkan bahwa pada konsentrasi BAP yang rendah (1 atau 2 $\mathrm{mg} / \mathrm{L}$ ), pemberian $0,5 \mathrm{mg} / \mathrm{L}$ TDZ dapat meningkatkan jumlah tunas, namun pada konsentrasi BAP yang tinggi (5 $\mathrm{mg} / \mathrm{L})$ penambahan $0,5 \mathrm{mg} / \mathrm{L}$ TDZ tidak berpengaruh nyata (Tabel 2, Gambar 2). Respon serupa ditunjukkan pada tanaman manggis, kombinasi BAP 2 atau $4 \mathrm{mg} / \mathrm{L}$ dengan TDZ 0,05 $\mathrm{mg} / \mathrm{L}$ menghasilkan multiplikasi tunas terbaik (Lestari et al. 2013). Menurut Guo et al. (2011), interaksi antara BAP dan TDZ bersifat saling melengkapi, karena keduanya dapat terikat pada reseptor yang sama yaitu cytokininbinding protein (CBP). Reseptor ini yang memiliki 2 sisi aktif pengikatan yaitu satu sisi mengikat sitokinin alami berbasis adenin (BAP) sedangkan sisi yang lainnya mengikat sitokinin berbasis phenylurea (TDZ). Penggunaan BAP dan TDZ secara bersamaan diduga akan mengaktifkan kedua sisi pengikatan CBP sehingga akan meningkatkan pembentukan tunas.

ZPT dari golongan sitokinin seperti benzyl amino purine (BAP) berperan penting dalam memacu proses pembelahan sel, khususnya didalam proses regenerasi tunas, menstimulasi pertumbuhan tunas lateral dan menghasilkan tunas ganda (Lestari 2011). Selain BAP, penggunaan TDZ juga sangat efektif dalam mendukung pembentukan dan penggandaan tunas in vitro (George et al. 2008). TDZ merupakan senyawa organik yang banyak digunakan dalam perbanyakan in vitro karena aktivitasnya menyerupai sitokinin. TDZ dapat diberikan bersama-sama dengan ZPT lain, seperti sitokinin atau auksin, dan dapat pula sendiri, namun perlakuan bersamasama dengan ZPT lain lebih baik hasilnya (Hutchinson et al. 2010).
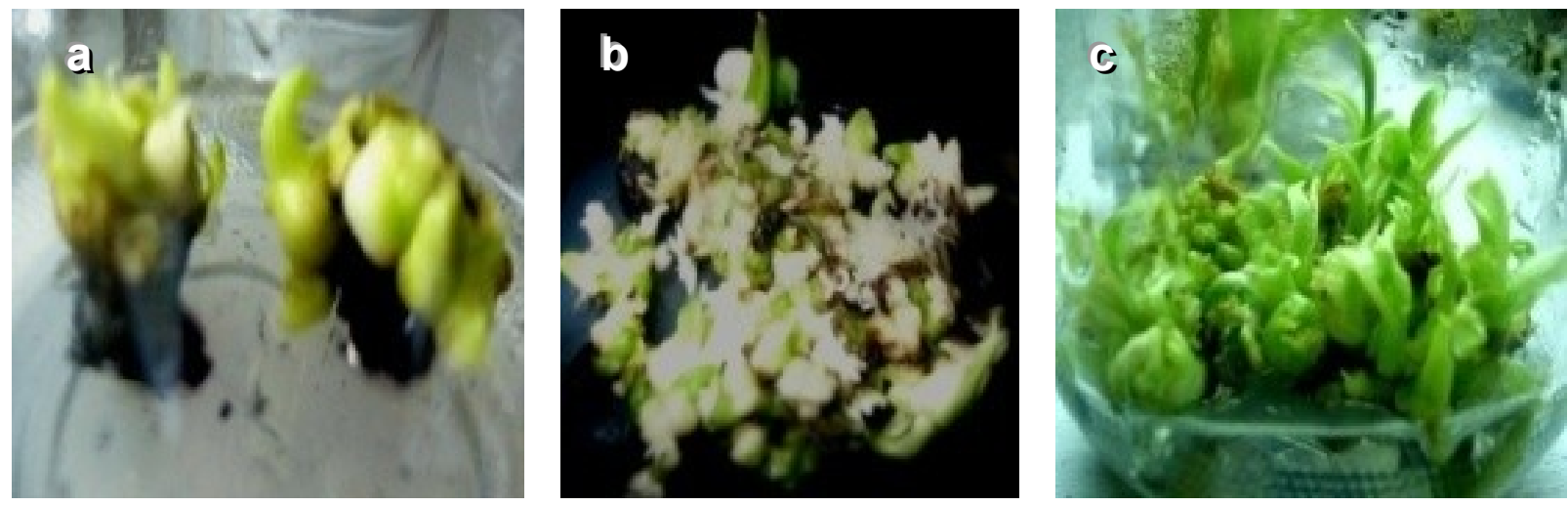

Gambar 1. Proliferasi tunas in vitro pisang kepok Unti Sayang: (a). Bakal tunas umur 4 minggu, (b). Bakal tunas umur 8 minggu, (c). Tunas umur 12 minggu 


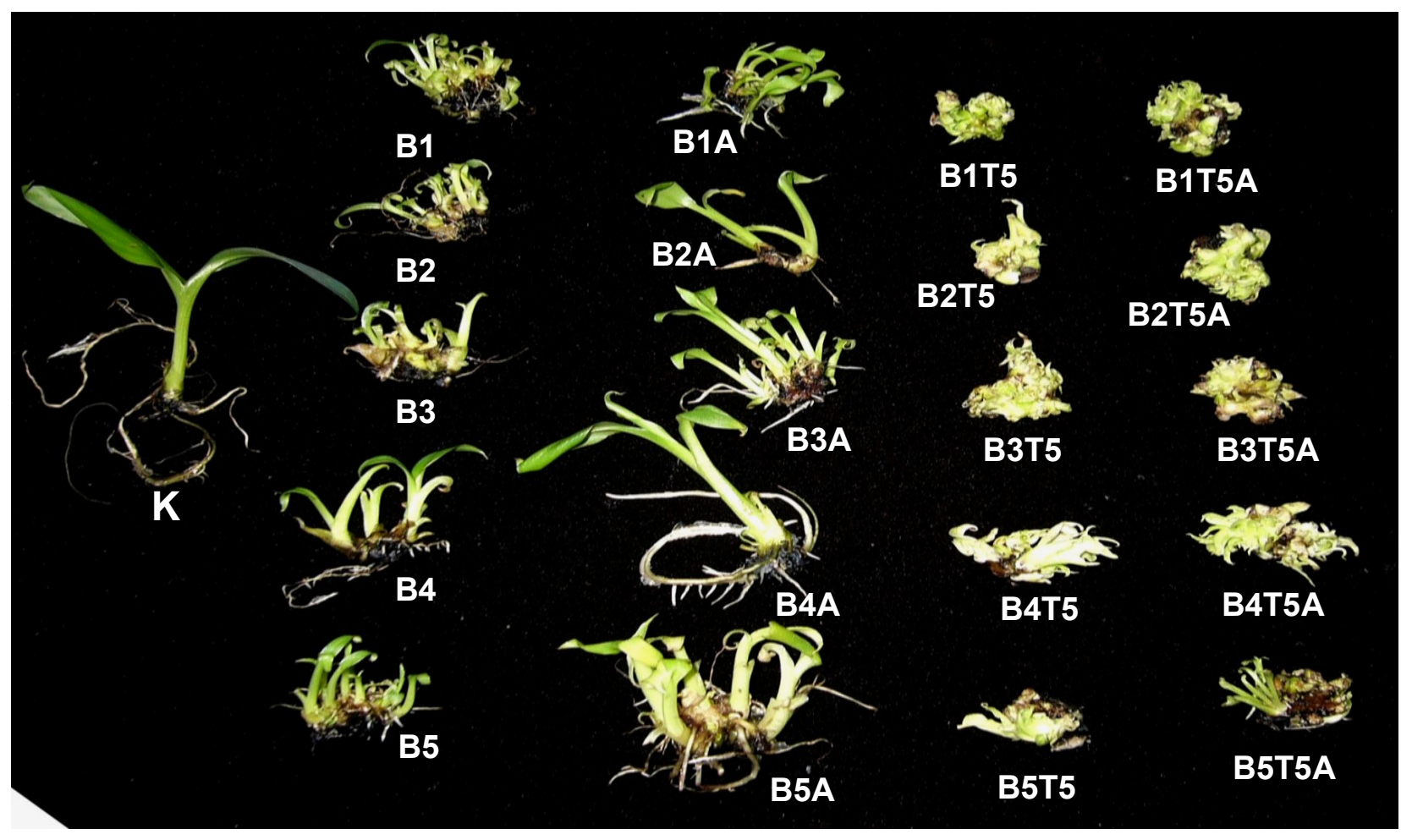

Gambar 2. Tunas in vitro pisang kepok Unti Sayang dari berbagai perlakuan umur 6 minggu setelah kultur

Tabel 2. Pengaruh kombinasi BAP, TDZ dan adenin sulfat terhadap jumlah dan tinggi tunas in vitro pisang kepok Unti Sayang

\begin{tabular}{|c|c|c|c|c|c|c|}
\hline \multirow{2}{*}{ Media } & \multicolumn{3}{|c|}{ Jumlah tunas (cm) } & \multicolumn{3}{|c|}{ Tinggi tunas $(\mathrm{cm})$} \\
\hline & 4 minggu & 8 minggu & 12 minggu & 4 minggu & 8 minggu & 12 minggu \\
\hline $\mathrm{B}_{1}$ & $9,07^{\text {hij }}$ & $17,67^{\text {hij }}$ & $30,17^{\mathrm{fgh}}$ & $2,00^{\text {cde }}$ & $3,00^{\text {cd }}$ & $2,41^{\text {bcde }}$ \\
\hline $\mathrm{B}_{1} \mathrm{~A}$ & $8,80^{\text {ghij }}$ & $17,00^{g h i}$ & $28,00^{\text {fgh }}$ & $2,17^{\text {cde }}$ & $2,60^{\mathrm{cd}}$ & $2,58^{\text {cde }}$ \\
\hline $\mathrm{B}_{1} \mathrm{~T}_{5}$ & $5,60^{\text {def }}$ & $21,00^{\mathrm{ij}}$ & $32,33^{g h}$ & $0,57^{\mathrm{a}}$ & $1,00^{a}$ & $1,00^{a}$ \\
\hline $\mathrm{B}_{1} \mathrm{~T}_{5} \mathrm{~A}$ & $6,53^{\text {efg }}$ & $14,33^{\mathrm{fgh}}$ & $24,00^{\text {ef }}$ & $0,67^{\mathrm{a}}$ & $1,33^{\mathrm{ab}}$ & $1,33^{a b}$ \\
\hline $\mathrm{B}_{2}$ & $8,57^{\text {ghij }}$ & $15,36^{\mathrm{fgh}}$ & $25,30^{\text {ef }}$ & $1,95^{\text {cde }}$ & $2,00^{\mathrm{abc}}$ & $2,50^{\text {bcde }}$ \\
\hline $\mathrm{B}_{2} \mathrm{~A}$ & $6,74^{\mathrm{efg}}$ & $13,69^{\text {efgh }}$ & $25,18^{\mathrm{ef}}$ & $2,15^{\mathrm{cde}}$ & $2,65^{\mathrm{bcd}}$ & $3,02^{\text {def }}$ \\
\hline $\mathrm{B}_{2} \mathrm{~T}_{5}$ & $12,70^{k}$ & $25,51^{j}$ & $33,95^{\mathrm{gh}}$ & $1,30^{\mathrm{abc}}$ & $1,40^{\mathrm{ab}}$ & $1,47^{\mathrm{abc}}$ \\
\hline $\mathrm{B}_{2} \mathrm{~T}_{5} \mathrm{~A}$ & $10,98^{\mathrm{jk}}$ & $35,44^{\mathrm{k}}$ & $36,81^{\mathrm{h}}$ & $0,97^{\mathrm{ab}}$ & $1,58^{\mathrm{a}}$ & $1,83^{\mathrm{abcd}}$ \\
\hline $\mathrm{B}_{3}$ & $6,80^{\mathrm{fgh}}$ & $10,67^{\text {cdef }}$ & $18,27^{\text {de }}$ & $1,83^{\mathrm{bcde}}$ & $2,16^{\mathrm{abc}}$ & $2,50^{\text {bcde }}$ \\
\hline $\mathrm{B}_{3} \mathrm{~A}$ & $5,20^{\text {cdef }}$ & $9,33^{\text {bcdef }}$ & $14,50^{\mathrm{bcd}}$ & $2,00^{\text {cde }}$ & $2,83^{\mathrm{cd}}$ & $2,83^{\mathrm{de}}$ \\
\hline $\mathrm{B}_{3} \mathrm{~T}_{5}$ & $3,23^{\mathrm{abcd}}$ & $9,00^{\text {bcdef }}$ & $15,17^{\text {bcd }}$ & $0,67^{a}$ & $1,17^{\mathrm{a}}$ & $1,17^{\mathrm{a}}$ \\
\hline $\mathrm{B}_{3} \mathrm{~T}_{5} \mathrm{~A}$ & $3,13^{a b c}$ & $11,67^{\text {defg }}$ & $18,67^{\mathrm{de}}$ & $1,17^{\mathrm{abc}}$ & $1,83^{a b c}$ & $1,83^{\mathrm{abcd}}$ \\
\hline $\mathrm{B}_{4}$ & $1,80^{\mathrm{a}}$ & $4,67^{\mathrm{ab}}$ & $9,00^{\mathrm{ab}}$ & $3,00^{\mathrm{fg}}$ & $3,40^{\mathrm{de}}$ & $3,50^{\mathrm{ef}}$ \\
\hline $\mathrm{B}_{4} \mathrm{~A}$ & $4,27^{\text {bcde }}$ & $11,33^{\text {def }}$ & $18,00^{\text {cde }}$ & $3,60^{9}$ & $4,17^{\mathrm{e}}$ & $4,17^{f}$ \\
\hline $\mathrm{B}_{4} \mathrm{~T}_{5}$ & $4,20^{\text {bcde }}$ & $5,67^{\mathrm{abc}}$ & $8,50^{\mathrm{ab}}$ & $0,50^{\mathrm{a}}$ & $1,00^{\mathrm{a}}$ & $1,00^{\mathrm{a}}$ \\
\hline $\mathrm{B}_{4} \mathrm{~T}_{5} \mathrm{~A}$ & $5,73^{\text {ef }}$ & $7,00^{\mathrm{abcd}}$ & $10,17^{\mathrm{abc}}$ & $0,50^{\mathrm{a}}$ & $1,00^{a}$ & $1,00^{a}$ \\
\hline $\mathrm{B}_{5}$ & $10,88^{\mathrm{ijk}}$ & $17,52^{\mathrm{ghi}}$ & $25,45^{\mathrm{efg}}$ & $1,98^{\mathrm{bcd}}$ & $2,02^{a b c}$ & $2,40^{\text {bcde }}$ \\
\hline $\mathrm{B}_{5} \mathrm{~A}$ & $7,62^{\text {fghi }}$ & $11,76^{\text {cdef }}$ & $24,80^{\text {ef }}$ & $2,00^{\text {cde }}$ & $2,78^{\mathrm{cd}}$ & $3,10^{\text {ef }}$ \\
\hline $\mathrm{B}_{5} \mathrm{~T}_{5}$ & $1,13^{\mathrm{a}}$ & $2,07^{\mathrm{a}}$ & $3,33^{a}$ & $0,50^{a}$ & $1,00^{a}$ & $1,00^{a}$ \\
\hline $\mathrm{B}_{5} \mathrm{~T}_{5} \mathrm{~A}$ & $6,63^{\text {efg }}$ & $8,67^{\text {bcde }}$ & $12,67^{\mathrm{bcd}}$ & $0,50^{a}$ & $1,00^{a}$ & $1,00^{a}$ \\
\hline Kontrol & $2,60^{\mathrm{ab}}$ & $2,68^{\mathrm{a}}$ & $3,00^{\mathrm{a}}$ & $2,50^{\text {ef }}$ & $3,00^{c d}$ & $3,60^{\text {ef }}$ \\
\hline
\end{tabular}

Keterangan: Perbedaan huruf menunjukkan berbeda nyata berdasarkan DMRT pada taraf 5\% 
Penggunaan BAP pada penelitian kultur jaringan pisang kepok telah banyak dilakukan. Pada pisang kultivar kepok merah, multiplikasi tunas tertinggi diperoleh pada media MS yang ditambahkan IAA 0,5 $\mathrm{mg} / \mathrm{L}$ dan BAP $5 \mathrm{mg} / \mathrm{L}$. Pada media tersebut dihasilkan 6-17 tunas per eksplan dalam waktu 8 hari setelah tanam (Fitramala et al. 2016). Pada pisang kepok Amorang, penggunaan BAP pada konsentrasi $1 \mathrm{mg} / \mathrm{L}$ dalam $1 / 4$ MS merupakan media terbaik untuk multiplikasi tunas (Supriati 2010). Subkultur berulang pisang kepok var. Unti Sayang pada media MS yang ditambahkan $2 \mathrm{mg} / \mathrm{L}$ BAP dan 0,8 $\mathrm{mg} / \mathrm{L}$ TDZ tidak mampu meningkatkan multiplikasi tunas (Semarayani 2012).

Pemberian adenin sulfat $20 \mathrm{mg} / \mathrm{L}$ pada media yang mengandung BAP konsentrasi rendah (1-2 mg/L) dengan atau tanpa TDZ secara statistik tidak berpengaruh nyata terhadap peningkatan jumlah tunas in vitro, namun nilai rata-rata yang diperoleh lebih tinggi dibandingkan tanpa penambahan adenin sulfat. Adenin termasuk sitokinin alami. Adenin berperan sebagai prekursor pada biosintesis sitokinin. Adenin sering kali menunjukkan pengaruh yang serupa dengan sitokinin yaitu menginduksi pembentukan tunas (Van Staden et al. 2008). Pada beberapa tanaman, penambahan adenin sulfat pada media yang mengandung BAP atau kinetin mampu menghasilkan banyak tunas aksilar, seperti pada tanaman buncis (Arias et al. 2010), Fuchsia hybrida (Wroblewska 2012) dan Stevia rebaudiana Bertoni (Khan et al. 2014).

Respon terbaik pertambahan tinggi tunas pisang Unti Sayang yaitu pada media $\mathrm{B}_{4} \mathrm{~A} \quad(\mathrm{MS}+4 \mathrm{mg} / \mathrm{L} \quad \mathrm{BAP}+20 \mathrm{mg} / \mathrm{L}$ adenin sulfat). Penambahan adenin sulfat pada media yang mengandung BAP saja menunjukkan pertumbuhan tunas yang lebih tinggi dibandingkan tunas yang ditanam pada media tanpa penambahan adenin sulfat, walaupun secara statistik tidak berbeda nyata. Demikian pula penambahan adenin sulfat pada media yang mengandung BAP dan TDZ menunjukkan tunas yang lebih tinggi dibandingkan tunas yang ditanam pada media tanpa penambahan adenin sulfat. Penambahan TDZ pada media cenderung mengakibatkan terbentuknya banyak tunas namun menghambat pertumbuhan atau pertambahan tinggi tunas sehingga dihasilkan tunas kerdil atau pendek (Tabel 2, Gambar 2). Untuk menghindari respon seperti itu, maka disarankan perbanyakan tunas in vitro pisang Unti Sayang pada media MS+0,5 mg/L TDZ+2 $\mathrm{mg} / \mathrm{L}$ BAP tidak lebih dari 8 minggu.

\section{Pengakaran tunas in vitro}

Pengakaran tunas dapat dengan mudah dilakukan dengan memindahkan tunas yang sudah cukup besar (umur 8 minggu setelah tanam) dari media perlakuan ke media MS tanpa ZPT (Gambar 3B). Akar juga sudah terbentuk pada beberapa perlakuan seperti $B_{2}$ dan $B_{2} A$ namun jumlahnya terbatas. Oleh sebab itu pengakaran tunas sebaiknya dilakukan pada media kontrol tanpa ZPT. Penambahan auksin seperti IBA atau NAA ke dalam media pengakaran nampaknya tidak diperlukan karena akar yang terbentuk pada media kontrol sudah cukup banyak.

\section{Aklimatisasi planlet}

Perbanyakan secara in vitro dinyatakan berhasil apabila planlet mampu melewati masa aklimatisasi dan dihasilkan bibit yang siap tanam. Aklimatisasi planlet pisang Unti Sayang tidak menemui banyak kendala. Aklimatisasi telah dilakukan terhadap 666 planlet, 617 planlet hidup dan hanya 49 planlet yang mati. Planlet yang berhasil hidup mencapai 92,75\%. Penggunaan media untuk aklimatisasi yaitu tanah, kompos dan sekam bakar (1:1:1) serta tahapan aklimatisasi yang dilakukan menunjukkan hasil yang optimal. Seperti pada aklimatisasi pisang Raja Nangka, Kepok dan Mas yang menunjukkan tingkat keberhasilan aklimatisasi mencapai 90\% dengan menggunakan media campuran tanah, pasir dan kompos dengan perbandingan 1:1:1 (Avivi et al. 2013). Proses aklimatisasi dapat dilihat pada Gambar 4.

\section{KESIMPULAN}

Proliferasi tunas in vitro pisang kepok var. Unti Sayang menunjukkan hasil terbaik pada media $B_{2} T_{5} A(2 \mathrm{mg} / \mathrm{L}$ BAP, 0,5 mg/L TDZ dan $20 \mathrm{mg} / \mathrm{L}$ adenin sulfat) yang menghasilkan 35,44 tunas pada umur 8 minggu. Berdasarkan penelitian ini, maka untuk metode perbanyakan tunas in vitro 

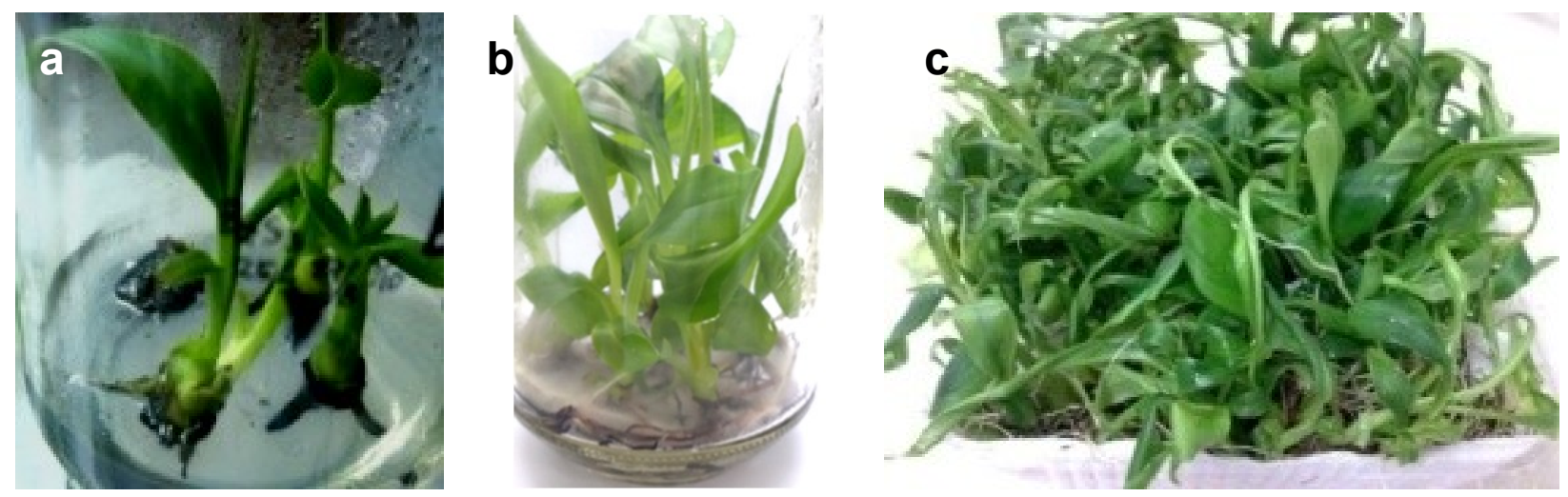

Gambar 3. Planlet pisang kepok Unti Sayang: (a). Tunas yang baru membentuk akar, (b). Planlet yang sudah berakar banyak, (c). Tunas siap untuk aklimatisasikan
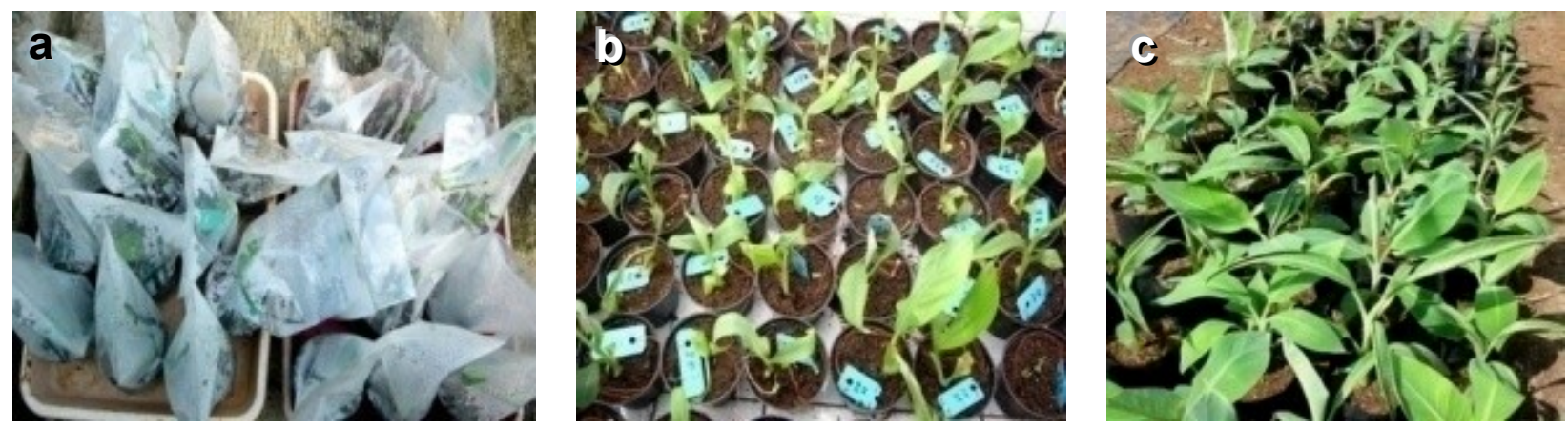

Gambar 4. Aklimatisasi planlet pisang kepok Unti Sayang: (a). Planlet dalam sungkup plastik, (b). Bibit setelah sungkupnya dibuka (umur 2 minggu), (c). Bibit umur 4 minggu

yang optimal adalah proliferasi tunas in vitro pada media $B_{2} T_{5} A$ selama tidak lebih dari 8 minggu kemudian dilanjutkan ke media tanpa ZPT untuk pertambahan tinggi dan pengakarannya.

\section{UCAPAN TERIMA KASIH}

Penulis mengucapkan terima kasih kepada Sdr. Mulyana untuk pemeliharaan kultur serta Sdr. Nana Burhana untuk pemeliharaan tanaman di rumah kaca dan kebun. Penelitian ini didanai oleh Proyek Kompetitif LIPI, Sub-Program Keanekaragaman Sumber Daya Hayati.

\section{DAFTAR PUSTAKA}

Arias AMG, Valverde JM, Fonseca PR, Melara MV (2010) In vitro plant regeneration system for common bean (Phaseolus vulgaris): Effect of $\mathrm{N}^{6}$ benzylaminopurine and adenine sulphate. Electron J Biotechnol 13 (Issue 1). doi: 10.2225-vol13-issue1fulltext-7
Avivi S, Soedarmo SH, Prasetyo PA (2013) Multiplikasi tunas dan aklimatisasi tiga varietas pisang: Raja Nangka, Kepok, dan Mas. J Hort Indones 4: 83-89

Eden-Green SJ (1994) Banana blood disease. International Network for the Improvement of Banana and Plantain (INIBAP). Musa Disease Fact Sheet No.3. Montpellier, France

Fitramala E, Khaerunisa E, Djuita NR, Sunarso H, Ratnadewi D (2016) Kultur in vitro pisang (Musa paradisiaca L.) cv. Kepok Merah untuk mikropropagasi cepat. Menara Perkebunan 84: 69-75. doi:10.22302/iribb.jur.mp.v84i2.221

George EF, Hall MA, De Klerk G-J (2008) Plant Propagation by Tissue Culture. Volume 1: The Background. $3^{\text {rd }}$ Edition. Springer-Verlag, New York

Guo B, Abbasi BH, Zeb A, Xu LL, Wei YH (2011) Thidiazuron: A multi-dimentional plant growth regulator. Afr J Biotechnol 10: 8984-9000. doi: 10.5897/AJB11.636

Hermanto C, Emilda ED (2013) Bunch management of banana to control 
blood disease. Aust Plant Pathol 42: 653-658

Hutchinson MJ, Onamu R, Kipkosgei L, Obukosia SD (2010) Effect of thidiazuron, NAA and BAP on in vitro propagation of Alstroemeria aurantiaca cV 'ROSITA' from shoot tip explants. J Agric Sci Technol 12: 60-69

Khan MK, Misra P, Sharma T, Shukla PK, Ramteke PW (2014) Effect of adenine sulphate on in vitro mass propagation of Stevia rebaudiana Bertoni. J Med Plant Res 8: 543-549. doi: 10.5897/JMPR2013.5217

Lestari EG (2011) Peranan zat pengatur tumbuh dalam perbanyakan tanaman melalui kultur jaringan. J AgroBiogen 7: 63-68.

doi: 10.21082/jbio.v7n1.2011.p63-68

Lestari EG, Suhartanto MR, Kurniawati $A$, Rahayu S (2013) Inisiasi tunas ganda tanaman manggis Malinau melalui kultur in vitro untuk perbanyakan klonal. J Agron Indones 41: 40-46

Maramis RTD (2014) Insidensi penyakit darah pisang di Kabupaten Minahasa Utara. J IImiah Sains 14: 35-45

Murashige T, Skoog F (1962) A revised medium for rapid growth and bioassays with tobacco tissue cultures. Physiol Plant 15: 473-497. doi: 10.1111/j.1399-3054.1962.tb08052.x

Poerba YS, Imelda M, Martanti D (2012) Analisis kestabilan genetik pisang kepok 'Unti Sayang' hasil mikropropagasi dengan marka RAPD dan ISSR. Berita Biologi. 11: 275-282. doi: 10.14203/beritabiologi.v11i2.497

Semarayani CIM (2012) Subkultur berulang tunas in vitro pisang kepok Unti Sayang pada beberapa komposisi media. Skripsi. Fakultas Pertanian. Institut Pertanian Bogor

Suhartanto MR, Sobir, Harti H, Nasution MA, Nurbani (2012) Pengembangan pisang kepok unggul sebagai penopang ketahanan pangan nasional. Hal 444448. Prosiding Simposium dan Seminar Bersama PERAGIPERHORTI-PERIPI-HIGI. Mendukung Kedaulatan Pangan dan Energi yang Berkelanjutan. 1-2 Mei 2012, Bogor

Supriati Y (2010) Efisiensi mikropropagasi pisang kepok Amorang melalui modifikasi formula media dan temperatur. J AgroBiogen 6: 91-100. doi: 10.21082/jbio.v6n2.2010.p91-100

Van Staden J, Zazimalova E, George EF (2008) Plant growth regulators II: Cytokinins, their analogues and antagonists. Pp 205-226. In: Plant Propagation by Tissue Culture. Volume 1: The Background. $3^{\text {rd }}$ Edition. George EF, Hall MA, De Klerk G-J (Eds). Springer, Dordrecht

Wroblewska K (2012) The influence of adenine and benzyladenine on rooting and development of Fuchsia hybrida cuttings. Acta Agrobotanica 65: 101108. doi: 10.5586/aa.2012.026 